\title{
Cover crops affect the soil chemical properties under no-till system
}

\author{
Simone Cândido Ensinas ${ }^{1}$, Ademar Pereira Serra*², Marlene Estevão Marchetti ${ }^{1}$, Eulene Francisco da \\ Silva $^{3}$, Elaine Reis Pinheiro Lourente ${ }^{1}$, Eber Augusto Ferreira do Prado ${ }^{1}$, Flávia Araújo Matos ${ }^{1}$, Pedro \\ Henrique Altomar ${ }^{1}$, Matheus Andrade Martinez ${ }^{1}$, Douglas Costa Potrich ${ }^{1}$, Vanessa do Amaral \\ Conrad $^{1}$, Maílson Vieira Jesus ${ }^{1}$, Tárik Cazeiro El Kadri ${ }^{1}$
}

\author{
${ }^{1}$ Universidade Federal da Grande Dourados (UFGD), City of Dourados, State of Mato Grosso do Sul, Brazil \\ ${ }^{2}$ Brazilian Agricultural Research Corporation (EMBRAPA), City of Campo Grande, State of Mato Grosso do \\ Sul, Brazil \\ ${ }^{3}$ Faculdade de Ciências Agrárias/Universidade Federal Rural do Semi-Árido (UFERSA), City of Mossoró, State \\ of Rio Grande do Norte, Brazil
}

*Corresponding author: ademar.serra@embrapa.br

\begin{abstract}
The purpose of this study was to assess the changes in soil chemical properties affected by the cover crops cultivated in crop rotation in short-term of no-till implementation under Rhodic Hapludox soil. This research was carried out from October 2010 to February 2014. The experiment was set up in completely randomized blocks in a factorial design with eight treatments (cover crops) and three soil depths $\left(0-5,5-10\right.$ and 10-20 cm) with four repetitions. The cover crops were: fall-winter maize $\left(\mathrm{T}_{1}\right)$, intercropping fall-winter maize with $B$. ruziziensis $\left(\mathrm{T}_{2}\right)$, intercropping fall-winter maize with $B$. brizantha cv. Marandu $\left(\mathrm{T}_{3}\right)$, intercropping fall-winter maize with Crotalaria spectabilis $\left(\mathrm{T}_{4}\right)$, B. ruziziensis $\left(\mathrm{T}_{5}\right)$, B. brizantha cv. Marandu $\left(\mathrm{T}_{6}\right)$, Pennisetum glaucum $\mathrm{L} .\left(\mathrm{T}_{7}\right)$ and fallow $\left(\mathrm{T}_{8}\right)$. The $\mathrm{T}_{6}$ and $\mathrm{T}_{7}$ affected exchangeable $\mathrm{Mg}^{+2}$, it was observed higher exchangeable $\mathrm{Mg}^{+2}$ in $\mathrm{T}_{6}\left(2.39 \mathrm{cmol}_{\mathrm{c}} \mathrm{dm}^{-3}\right)$ and $\mathrm{T}_{7}\left(2.43 \mathrm{cmol}_{\mathrm{c}} \mathrm{dm}^{-3}\right)$ in comparison to $\mathrm{T}_{1}$. The phosphorus content showed interactive effect between cover crops and soil depth. In the comparison among the depths, the $\mathrm{P}$ contents were higher in $5-10 \mathrm{~cm}$, which showed improvement of $24.6 \%$ and $25.2 \%$ in comparison to $0-5$ and $10-20$ $\mathrm{cm}$ layers, respectively. The cover crops evaluated in this research affected the exchangeable $\mathrm{Mg}^{+2}$ and $\mathrm{K}^{+}$, as well as $\mathrm{Mg}^{+2}$ and $\mathrm{K}^{+}$ saturation. The $\mathrm{P}$ content changed in response of cover crops, which was important to observe that this nutrient may increase the content with adoption of cover crops in no-till system. The species used in this research might be recommended to integrate a crop rotation system with the possibility of increasing $\mathrm{P}$ availability in topsoil depth in no-till system.
\end{abstract}

Keywords: Sustainability, phosphorus content, soil fertility, crop rotation. Abbreviations: $\mathrm{Mg} \mathrm{ha}^{-1} \_$ton ha ${ }^{-1}$; CEC_Cation Exchange Capacity.

\section{Introduction}

In Brazilian savannah "Cerrado", researchers are looking for conservative system of agricultural that promotes improvement in soil chemical, physical and biological properties, in this point of view, the no-till system shows to be a great option to guarantee the sustainability of soil used in agricultural system (Sá et al., 2014; Dang et al., 2015).

An important step to implement a no-till system is the choice of the cover crops species to compile the crop rotation system, because in Brazilian "Cerrado" biome, the weather condition is quite limited during fall-winter season and it may delay the production and maintenance of crop residues belowground and aboveground. It is possible that, species in crop rotation might promote changes in soil chemical properties (Landry et al., 2014). because plants can uptake the nutrients in soil deeper layers and deposit in topsoil, recycling the nutrients in soil. The aboveground dry matter can release the nutrients from plant tissues through the process of mineralization; this process can change the dynamic of nutrients in the soil, according to Duda et al. (2003). The mineralization of SOM may release organic acid that can complex the exchangeable aluminum and manganese, which might decrease the toxic effect for plants (Zambrosi et al., 2008; Eimil-Fraga et al., 2015). Different root depth development of each species in crop rotation might contribute to increase nutrients availability in soil solution (Garcia et al., 2008; Calegari et al., 2013; Rosolem and Calonego, 2013).

Some researches indicate the possibility of cover crops residues changing the chemical soil, as the case of Bassegio et al. (2015) who observed that millet in crop rotation has higher average of exchangeable potassium. The cultivation of different species of plants can modify the nutrients dynamic in soil (Tiecher et al., 2012; Steiner et al., 2012; Landry et al., 2014). On one hand there are researches that indicate positive results and improvement of chemical soil through the cover crops; on the other hand researches that did not observe any difference in chemical soil properties (Moreti et al., 2007; Cunha et al., 2011).

In the state of Mato Grosso do Sul, Brazil, the millet (Pennisetum americanum L.), Crotalaria spectabilis and forage grass (Brachiaria spp.) are the cover crops options that have been used by farmers. The intercropping maize with 
Brachiaria spp. is an important system of production that must be well-known to be possible the implementation focusing on the benefits that this intercropping may bring into an agricultural system of production. However, due to the limited number of information about the soil chemical properties that are affected by these cover crops in intercropping, it is important to develop researches to understand the benefits or not of these systems. Especially about phosphorus content in soil, because in Brazilian "Cerrado" the low phosphorus content in soil is a challenge to obtain sustainability in agricultural system.

Based on the point of view above, the purpose of this study was to assess in short-term of no-till implementation the changes in chemical properties affected by the cover crops cultivated in crop rotation under Rhodic Hapludox soil.

\section{Results and discussion}

\section{Analysis of variance (ANOVA) of the parameters assessed}

It was taken the joint analysis to study the effects of cover crops and soil depths on soil chemical properties. Significant interaction $(p \leq 0.01)$ between cover crops and soil depths for phosphorus content in soil was obtained. There were effects $(\mathrm{p} \leq 0.01)$ of cover crops on exchangeable magnesium, exchangeable potassium, magnesium saturation and potassium saturation. In relation to soil depths, it was observed significant effects $(\mathrm{p} \leq 0.01)$ for all variables assessed in this study.

\section{Soil depth effects on soil chemical properties}

The soil acidity increased in deeper depth, that was observed higher values of soil $\mathrm{pH}$ in topsoil (0-5 cm depth) (Fig 1). The potential acidity $(\mathrm{H}+\mathrm{Al})$ and exchangeable aluminum showed higher values in 10-20 cm depth, which differed statistically $(\mathrm{p} \leq 0.01)$ from the topsoil (Fig 1). Due to no-till system, the liming is broadcast in soil surface; this application may decrease the effects of liming in deeper layers. Even with the incorporation of liming in the beginning of the experiment implementation in soil profile of $0-20 \mathrm{~cm}$, this effect is not long lasting. As reported by Calegari et al. (2013), in evaluation of long-term experiment, the broadcast of liming on soil surface in no-till system was not efficient to correct the soil $\mathrm{pH}$ and aluminum exchangeable in deeper layers. This effect of decreasing soil $\mathrm{pH}$ in deeper layer is not observed in all cases, because in a no-till system evaluated by Abdollahi and Munkholm (2013), the value of soil $\mathrm{pH}$ increased in deeper layer $(10-20 \mathrm{~cm})$. The exchangeable $\mathrm{Ca}^{+2}$ and $\mathrm{Mg}^{+2}$ decreases through the soil profile, that can be associated with the result of decreasing soil $\mathrm{pH}$ (Fig 1). In general, the exchangeable $\mathrm{Ca}^{+2}, \mathrm{Mg}^{+2}$ and $\mathrm{K}^{+}$, CEC, base saturation and sum of base showed higher value in topsoil (0$5 \mathrm{~cm})$ than in deeper layer $(10-20 \mathrm{~cm})$ (Fig 1). The increase of base saturation is associated with the liming surface broadcast and potassium in croplands, this way the accumulation of nutrients $\left(\mathrm{Ca}^{+2}, \mathrm{Mg}^{+2}\right.$ and $\left.\mathrm{K}^{+}\right)$in topsoil can be increased over time. Higher nutrient concentration in topsoil in no-till system was observed by Rheinheimer and Anghinoni (2003) and Agbede (2010). It was observed by Willekens et al. (2014) and Garcia et al. (2008) that potassium showed higher concentration in no-till system in topsoil than in deeper layer. These authors suggested that this increase was associated with the crop residues in no-till system and capacity of nutrients recycling by plants, promoting the no exchangeable potassium to exchangeable potassium, increasing the viability for plants uptake.
The accumulation of nutrients in topsoil and cation exchange capacity (CEC) in no-till system can be associated with nottill and maintenance of crop residues on soil surface, this leads to increase SOM (D'Haene et al., 2009). The CEC in Oxisol is very dependable of organic colloids, which implies that SOM may increase the CEC. Even with no difference observed for cover crops effects on CEC in this study, it is important to emphasize that all cover crops produced aboveground dry matter in high quantity (above $4 \mathrm{Mg} \mathrm{ha}^{-1}$ ) that remained in the soil surface covered (data not showed). This input of SOM may contribute to increase CEC in topsoil, but, it is important that CEC increases in deeper layer as well, and this is a challenge for soil scientist.

Base saturation, aluminum, hydrogen, calcium, magnesium and potassium saturation effects by soil depth

Aluminum and hydrogen saturation increase in deeper layers, this effect ought to be associated with decreasing in base saturation and $\mathrm{pH}$ in deeper layers (Fig 2). The effects of liming in deeper layers in no-till system is limited because of the absence of tillage, this way the carbonate decreases in deeper layers and aluminum and hydrogen take place in CEC. With the impossibility of place lime in deeper layers in no-till system after implementation, the carbonate tends to decrease over time. As reported by Wang et al. (2015), the decrease of carbonate in soil tends to increase the acidification, which results in increasing $\mathrm{Al}^{+3}$ and $\mathrm{H}^{+}$saturation in soil. The calcium, potassium and magnesium saturation were higher in topsoil, which differed from the other layers evaluated (Fig 2).

\section{Effects of cover crops on exchangeable and saturation of} magnesium and potassium

On one hand, the treatment $\mathrm{T}_{6}$ and $\mathrm{T}_{7}$ effects on exchangeable $\mathrm{Mg}^{+2}$, which was observed higher exchangeable $\mathrm{Mg}^{+2}$ in $\mathrm{T}_{6}$ $\left(2.39 \mathrm{cmol}_{\mathrm{c}} \mathrm{dm}^{-1}\right)$ and $\mathrm{T}_{7}\left(2.43 \mathrm{cmol}_{\mathrm{c}} \mathrm{dm}^{-1}\right)$ in comparison to $\mathrm{T}_{1}$, on the other hand, the $\mathrm{T}_{6}$ and $\mathrm{T}_{7}$ did not differ from the other treatments (Fig 3). In relation to the magnesium saturation, the highest value $(20.19 \%)$ was observed in the $\mathrm{T}_{6}$, which showed significant difference $(\leq 0.01)$ from $\mathrm{T}_{1}, \mathrm{~T}_{2}$ and $\mathrm{T}_{4}$, however the $\mathrm{T}_{6}$ did not differ from $\mathrm{T}_{3}, \mathrm{~T}_{5}, \mathrm{~T}_{7}$ and $\mathrm{T}_{8}$ (Fig 3). Higher values of saturation and exchangeable $\mathrm{Mg}^{+2}$ in the $\mathrm{T}_{6}$ and $\mathrm{T}_{7}$ can be an indicative of these cover crops capacity in promoting increase of magnesium in soil profile (0-20 cm depth). The greatest performance of these species of cover crops can be associated with the highest adaptability in "Cerrado" soil in Brazil, most of these species show deep root in soil and constantly renew their roots, furthermore these species have higher capacity in biomass production that can be able to produce high quantity of biomass and increase SOM and nutrients content in soil. As reported by Tilman et al. (2001), the diversity of species increase carbon stocks and benefit the soil quality much higher than monoculture.

It is possible that Brachiaria brizantha cv. Marandu $\left(\mathrm{T}_{6}\right)$ and millet $\left(\mathrm{T}_{7}\right)$ are more efficient in magnesium uptake and accumulation in their tissue. As reported by Torres et al. (2008), the Brachiaria brizantha cv. Marandu and millet showed higher magnesium content in their residues, $21.1 \mathrm{~kg}$ $\mathrm{ha}^{-1}$ and $22.6 \mathrm{~kg} \mathrm{ha}^{-1}$, respectively. The capacity of millet in promoting the highest value of exchangeable $\mathrm{Mg}^{+2}$ was observed by Andrioli and Prado (2012).

In relation to exchangeable $\mathrm{K}^{+}$, the highest content was observed in $\mathrm{T}_{8}$, which differed from the $\mathrm{T}_{4}, \mathrm{~T}_{6}$ and $\mathrm{T}_{7}$, however, there was no difference in relation to $\mathrm{T}_{4}, \mathrm{~T}_{6}$ and $\mathrm{T}_{7}$ (Fig 3). To $\mathrm{K}^{+}$saturation, the highest value was observed in 
Table 1. Some physical and chemical soil properties of the experimental site.

\begin{tabular}{lll}
\hline & Depths & \\
\cline { 2 - 3 } & $0-20 \mathrm{~cm}$ & $20-40 \mathrm{~cm}$ \\
\hline $\mathrm{pH}\left(\mathrm{CaCl}_{2}\right)$ & 5.10 & 4.66 \\
$\mathrm{SOM}\left(\mathrm{g} \mathrm{dm}^{-3}\right)$ & 28.0 & 19.0 \\
$\mathrm{P}\left(\mathrm{mg} \mathrm{dm}^{-3}\right)$ & 16.30 & 1.08 \\
$\mathrm{~K}^{+}\left(\mathrm{cmol}_{\mathrm{c}} \mathrm{dm}^{-3}\right)$ & 0.41 & 0.10 \\
$\mathrm{Ca}^{2+}\left(\mathrm{cmol}_{\mathrm{c}} \mathrm{dm}^{-3}\right)$ & 4.15 & 1.90 \\
$\mathrm{Mg}^{2+}\left(\mathrm{cmol}_{\mathrm{c}} \mathrm{dm}^{-3}\right)$ & 1.30 & 0.75 \\
$\mathrm{H}+\mathrm{Al}\left(\mathrm{cmol}_{\mathrm{c}} \mathrm{dm}^{-3}\right)$ & 4.98 & 4.83 \\
$\mathrm{Al}$ & 0 & 0.34 \\
$\mathrm{SB}\left(\mathrm{cmol}_{\mathrm{c}} \mathrm{dm}^{-3}\right)$ & 5.86 & 2.75 \\
$\mathrm{CEC}\left(\mathrm{cmol}_{\mathrm{c}} \mathrm{dm}^{-3}\right)$ & 10.84 & 7.58 \\
$\mathrm{BS}(\%)$ & 54.06 & 36.28 \\
$\mathrm{Clay}\left(\mathrm{g} \mathrm{kg}^{-1}\right)$ & 390 & \\
Sand $\left(\mathrm{g} \mathrm{kg}^{-1}\right)$ & 310 & \\
Silt $\left(\mathrm{g} \mathrm{kg}^{-1}\right)$ & 300 & \\
\hline
\end{tabular}

CEC: Cation Exchange Capacity; total acidity $\mathrm{pH} 7.0\left(\mathrm{H}^{+}+\mathrm{Al}^{+3}\right)$; Exchangeable $\left(\mathrm{KCl} 1 \mathrm{~mol} \mathrm{~L}^{-1}\right) \mathrm{Ca}^{+2}$, $\mathrm{Mg}^{+2}$ and $\mathrm{Al}^{+3}$; $\mathrm{SB}$ : Sum of Base $=\sum$ cations; $\mathrm{BS}$ : Base Saturation $=\left(\sum\right.$ cations $/$ CEC $) \times 100$.

Table 2. Treatments description.

\begin{tabular}{lll}
\hline Treatments $(\mathrm{T})$ & \multicolumn{1}{c}{ Cover crops } & Spring-summer season \\
\hline $\mathrm{T}_{1}$ & Fall-winter maize & Soybean \\
$\mathrm{T}_{2}$ & Intercropping fall-winter maize with B. ruziziensis & Soybean \\
$\mathrm{T}_{3}$ & Intercropping fall-winter maize with B. brizantha cv. Marandu & Soybean \\
$\mathrm{T}_{4}$ & Intercropping fall-winter maize with Crotalaria spectabilis & Soybean \\
$\mathrm{T}_{5}$ & Brachiaria ruziziensis & Soybean \\
$\mathrm{T}_{6}$ & Brachiaria brizantha cv. Marandu & Soybean \\
$\mathrm{T}_{7}$ & Pennisetum glaucum L. & Soybean \\
$\mathrm{T}_{8}$ & fallow & Soybean \\
\hline
\end{tabular}

$\mathrm{T}_{8}$, which differed from the $\mathrm{T}_{5}, \mathrm{~T}_{6}$ and $\mathrm{T}_{4}$, however there was no difference in comparison to $\mathrm{T}_{1}, \mathrm{~T}_{2}, \mathrm{~T}_{3}$ and $\mathrm{T}_{4}$ (Fig 3 ).

The highest exchangeable $\mathrm{K}^{+}$in $\mathrm{T}_{8}$ might be due to the absence of cover crops, that resulted in low nutrient requirement and recycling from deeper soil. Besides, in the area with cover crops, the highest part of potassium in the system soil and plant may be immobilized by plants decreasing the exchangeable potassium in soil (Rosolem and Calonego, 2013), but this potassium can become exchangeable through the mineralization process in soil.

\section{Cover crops and soil depth effects on phosphorus content in no-till system}

The $\mathrm{P}$ content showed interactive effect between cover crops and soil depth (Fig 4). In comparison among the cover crops, the $\mathrm{T}_{7}$ (millet) decreased the phosphorus content in 0-5 and 5$10 \mathrm{~cm}$ layer, in comparison with the other cover crops.

The millet is an adaptable crop in temperate regions, due to high root system and capacity of extract high quantity of nutrients from soil solution, especially phosphorus and potassium (Molina et al., 2000); these effects results in high amount of phosphorus in plant tissue decreasing in soil (Foloni et al., 2008). However, it is important to keep in mind that this decreases in phosphorus content does not mean in phosphorus lost, because with mineralization of crop residues this phosphorus may return into the soil.

The $T_{1}$ showed the highest phosphorus content in the layer $5-10 \mathrm{~cm}$, it showed significantly difference $(\mathrm{p} \leq 0.01)$ in relation to the layers $0-5$ and $10-20 \mathrm{~cm}$. In the $\mathrm{T}_{5}$, the phosphorus content was higher until $10 \mathrm{~cm}$ layer. In $\mathrm{T}_{6}(B$. brizantha cv. Marandu), the highest phosphorus content was observed in $0-5 \mathrm{~cm}$ layer (Fig 4). In general, in the comparison among the three depths evaluated, the phosphorus contents were higher in $5-10 \mathrm{~cm}$, which showed improvement of $24.6 \%$ and $25.2 \%$ in comparison to $0-5$ and
10-20 cm layers, respectively (Fig 4). The highest phosphorus content might be attributed to the no-till system and maintenance of crop residues on soil surface (Bassegio et al., 2015), and another possible explanation for phosphorus content in $5-10 \mathrm{~cm}$ is the fertilization in the rows crops in this soil layer $(5-10 \mathrm{~cm})$.

In general, considering the nutrient range optimum in soil for plant development, it was verified in this research that the fertilizer applied associated with the cover crops in no-till system increased the exchangeable $\mathrm{Ca}^{+2}, \mathrm{Mg}^{+2}, \mathrm{~K}^{+}$and sum of base, which was adequate for plant development. In relation to CEC, base saturation and soil $\mathrm{pH}$ until $10 \mathrm{~cm}$ depth showed adequate values and the potential acidity $(\mathrm{H}+\mathrm{Al})$ was considered an average range value. The exchangeable $\mathrm{Al}^{+3}$ and $\mathrm{pH}$ below $10 \mathrm{~cm}$ depth were classified as low score and phosphorus content observed in the soil was above the critical value $\left(9 \mathrm{mg} \mathrm{dm}^{-3}\right)$ (Ribeiro et al., 1999).

The utilization of cover crops improved soil chemical in notill system through the increasing of available nutrients, which is important to reduce the spending with fertilizer through the application of information like in this research to manage the nutrients in no-till system.

\section{Materials and methods}

\section{Site description}

This research was carried out from October 2010 to September 2013 in a Rhodic Hapludox, clayey texture, clay mineralogy is constituted mainly by $\mathrm{Al} / \mathrm{Fe}$ oxy-hydroxides, according to taxonomy of Santos et al. (2013), located in the municipality of Maracaju, State of Mato Grosso do Sul,

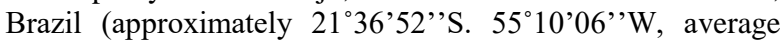
altitude $384 \mathrm{~m}$ above sea level). According to Köppen (1948), the region is classified as tropical climate of type Cwa, with 

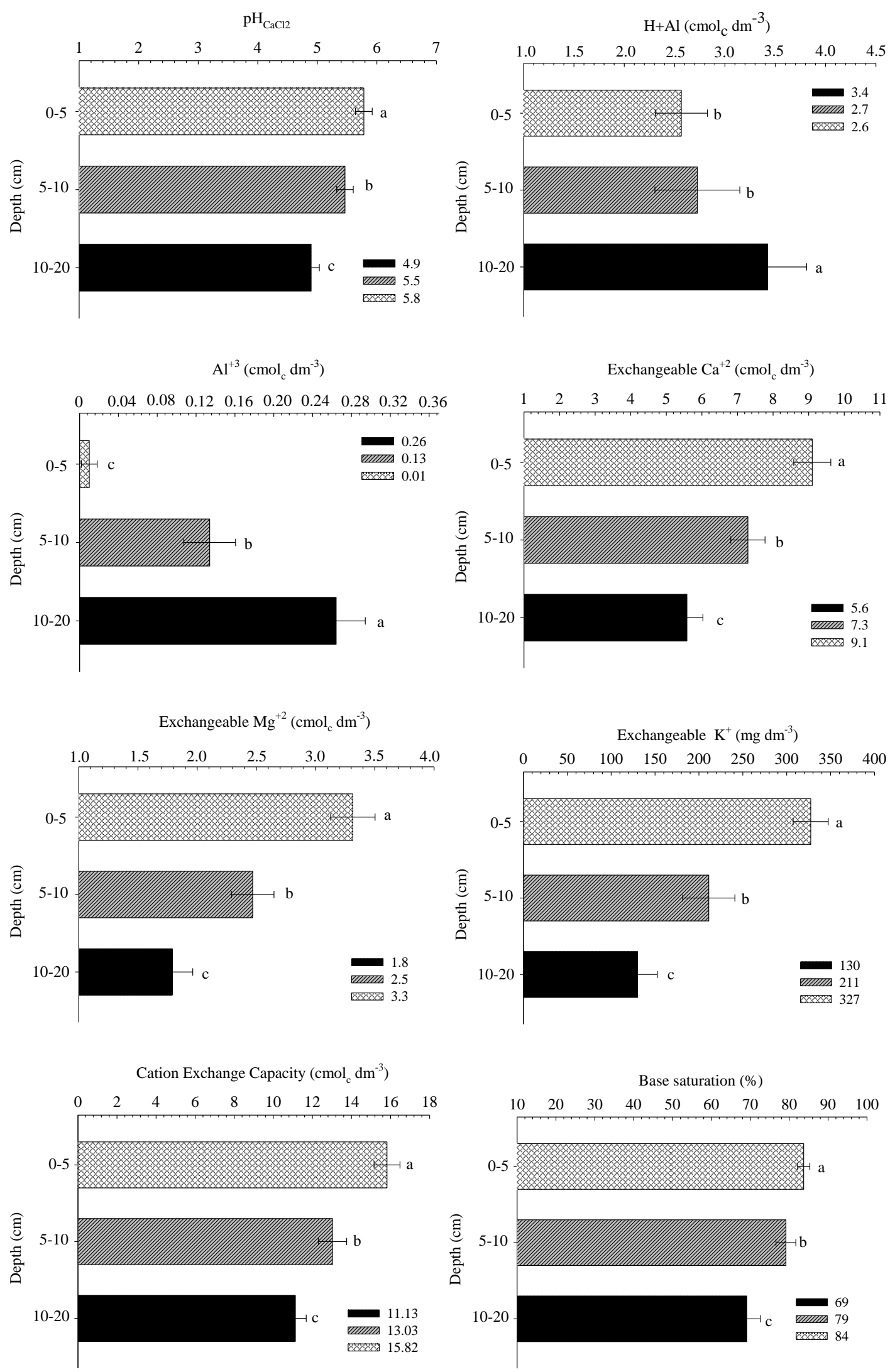

Fig 1. Soil chemical properties. Different letters indicate significant difference $(p \leq 0.05)$ among depths by Tukey test of means. The error bars are the standard errors. 

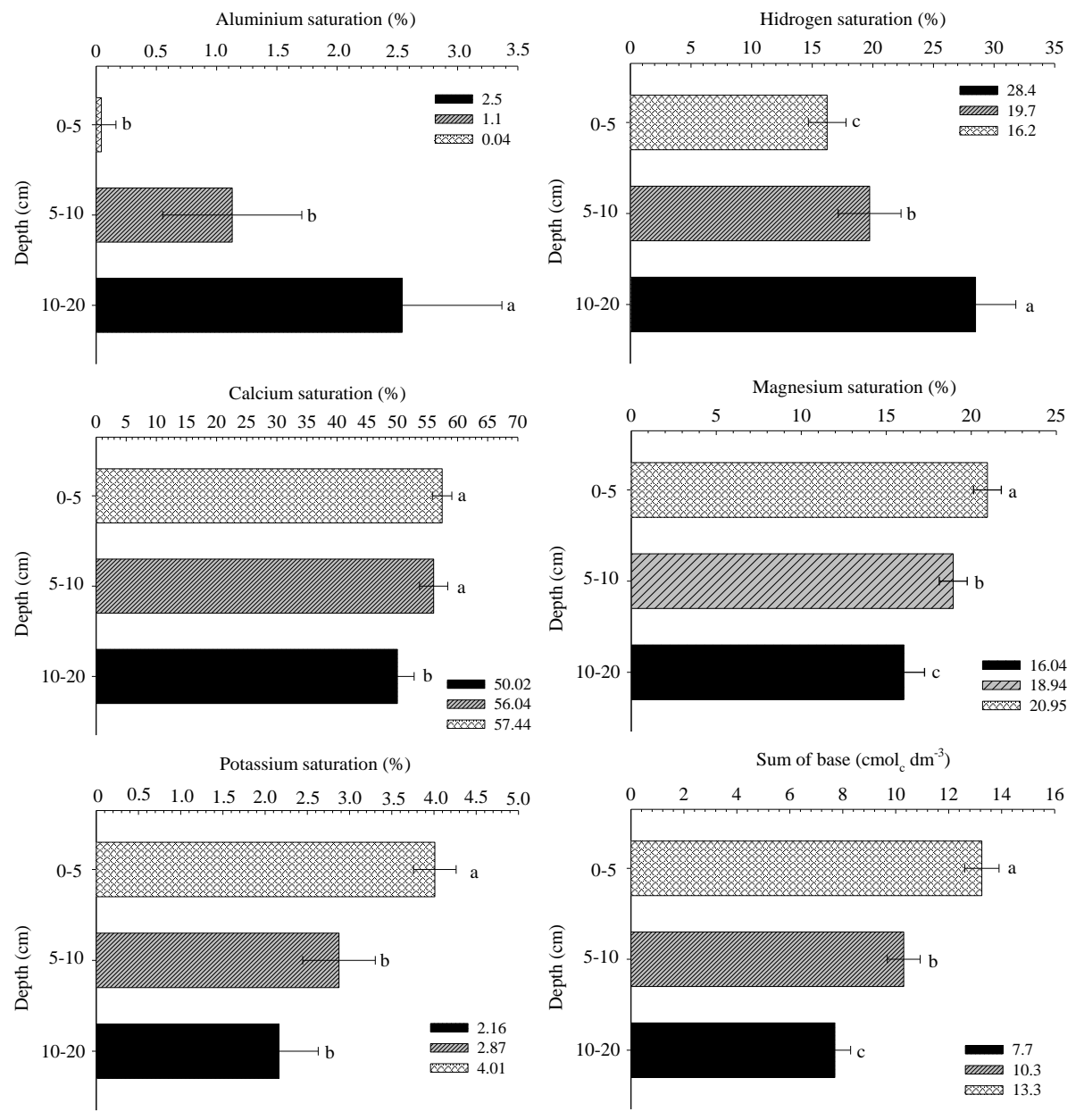

Fig 2. Soil chemical properties. Different letters indicate significant difference $(\mathrm{p} \leq 0.05)$ among depths by Tukey test of means. The error bars are the standard errors.

rainy summer and dry winter. The rainfall and temperature in the region of the experimental site is showed in Fig. 5.

\section{Historic of the area}

During ten years, the experimental area was cultivated with soybean in spring-summer and maize in fall-winter season. Before the implementation of the experiment in June $20^{\text {th }}$ 2010 , it was collected soil to analysis the chemical and physical properties, in 0-20 and 20-40 cm depth (Table 1).

The dolomitic lime $\left(2.4 \mathrm{Mg} \mathrm{ha}^{-1}\right)$ and gypsum $\left(\mathrm{CaSO}_{4} \cdot 2 \mathrm{H}_{2} \mathrm{O}\right)$ $\left(0.6 \mathrm{Mg} \mathrm{ha}^{-1}\right)$ were applied in 2010,30 days before soybeans sowed. The lime showed calcium carbonate equivalent (CCE) to $64 \%$. The lime and gypsum were accomplished by spreading on the soil without incorporation.

\section{Experimental design and treatments}

The experiment was carried out during three years, from 2010 to 2013. The assessments of the experiment were performed in September 2013. The experimental design was set up in completely randomized blocks with eight treatments (cover crops) and in three soil depths (0-5, 5-10 and 10-20 $\mathrm{cm}$ ) with four repetitions (Table 3). The experimental unit was set in a dimension of $12 \mathrm{~m} \times 2.5 \mathrm{~m}$. The treatments adopted were different cover crops sowed in the fall-winter season before soybean cultivation in the spring-summer season under no-till system (Table 2).

\section{Plant material and steps of treatments implementation}

The major species in the fallow were basically for the weeds for Bidens pilosa, Eleusine indica, Euphorbia heterophylla, Brachiaria spp. and Ipomoea grandifolia. The sowing of the fall-winter corn in the growing seasons was accomplished in no-till system right after the soybean harvest. It was used the fall-winter corn hybrid DKB 390 VTPRO. The sowing of fall-winter corn was executed depositing three seeds per meter in the spacing between rows of $50 \mathrm{~cm}$. At the moment of sowing in February of each year, the fertilizer was accomplished with $256 \mathrm{~kg} \mathrm{ha}^{-1}$ of the formulation 12-15-15 $\left(\mathrm{N}-\mathrm{P}_{2} \mathrm{O}_{5}-\mathrm{K}_{2} \mathrm{O}\right)$, this fertilizer recommendation was based on the results of soil chemical and adequate nutrient range according to Cantaruttti et al. (1999).

The intercropping fall-winter maize with forages grass $(B$. ruzizienses and $B$. brizantha cv. Marandu) was sowed at the same moment through the use of automatized machine. The space between rows for forages grass was $21 \mathrm{~cm}$. The seed cultural value for $B$. ruzizienses and $B$. brizantha $\mathrm{cv}$. Marandu were $50 \%$ and $80 \%$, respectively. Both species of forages grass showed seeds with $80 \%$ of germination and $62.5 \%$ of purity. To establish the intercropping fall-winter 

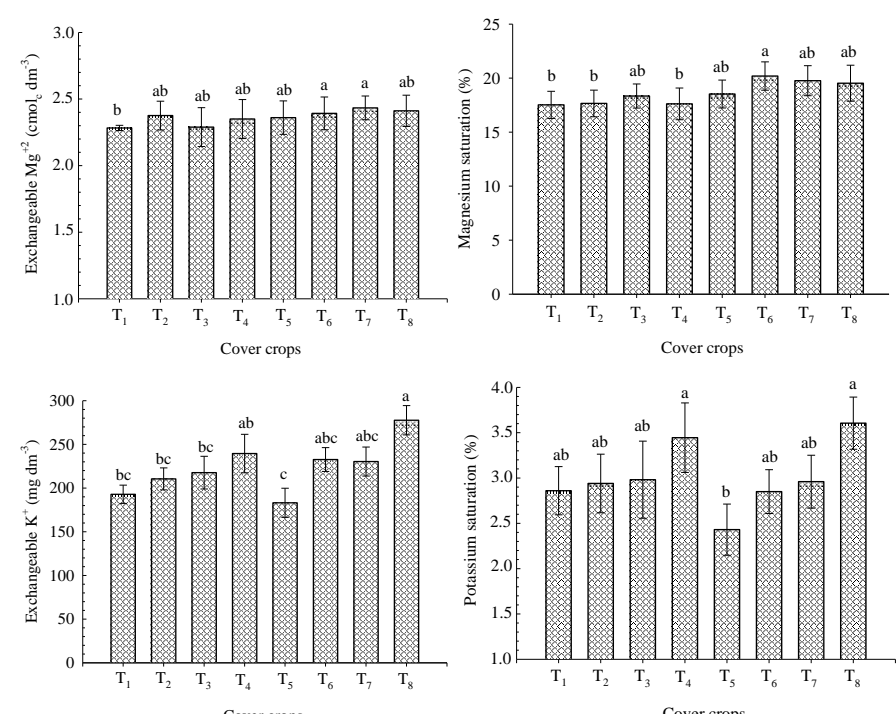

Fig 3. Cover crops effects on exchangeable and saturation magnesium and potassium. Different letters indicate significant difference $(p \leq 0.05)$ among cover crop by Tukey test of means. The error bars are the standard errors. $T_{1}$ Fall-winter maize; $T_{2}$ Intercropping fall-winter maize with $B$. ruziziensis; $\mathrm{T}_{3}$ Intercropping fall-winter maize with $B$. brizantha $\mathrm{cv}$. Marandu; $\mathrm{T}_{4-}$ Intercropping fall-winter maize with Crotalaria spectabilis; $\mathrm{T}_{5} \_$B. ruziziensis; $\mathrm{T}_{6 \_}$B. brizantha $\mathrm{cv}$. Marandu; $\mathrm{T}_{7 \_}$Pennisetum glaucum $\mathrm{L}_{\text {. }} ; \mathrm{T}_{8}$ fallow.

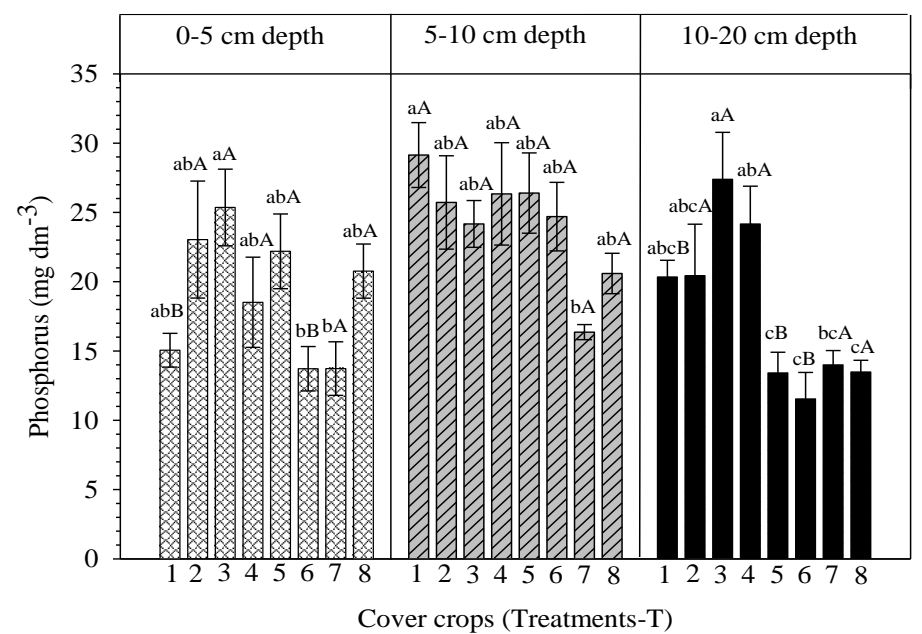

Fig 4. Interaction effects between cover crops and soil depths on phosphorus content in soil. Different uppercase letters indicate significant difference $(\mathrm{p} \leq 0.05)$ among depths within same cover crop while different lowercase letters indicate significant difference $(\mathrm{p} \leq 0.05)$ among cover crop by Tukey test of means. The error bars are the standard errors. $\mathrm{T}_{1} \_$Fall-winter maize; $\mathrm{T}_{2}$ Intercropping fall-winter maize with $B$. ruziziensis; $\mathrm{T}_{3}$ Intercropping fall-winter maize with $B$. brizantha $\mathrm{cv}$. Marandu; $\mathrm{T}_{4 \_}$Intercropping fall-winter maize with Crotalaria spectabilis; $\mathrm{T}_{5}$ B. ruziziensis; $\mathrm{T}_{6}$ B. brizantha $\mathrm{cv}$. Marandu; $\mathrm{T}_{7}$ Pennisetum glaucum $\mathrm{L}_{\text {. }} ; \mathrm{T}_{8_{-}}$fallow.

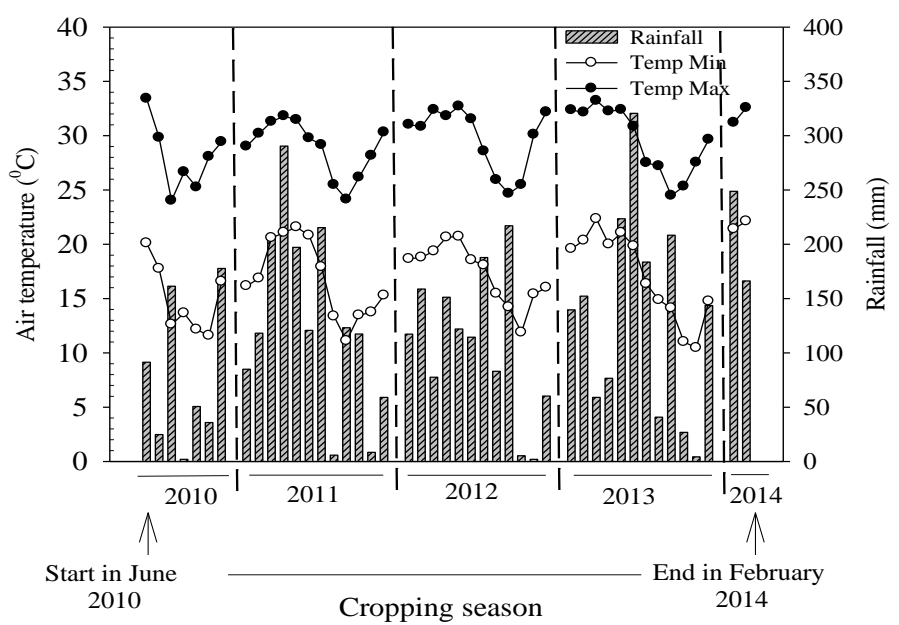

Fig 5. Monthly rainfall and temperature in the period from June 2010 to February 2014. 
corn with B. ruzizienses and B. brizantha $\mathrm{cv}$. Marandu, it was used 3.0 and $3.5 \mathrm{~kg} \mathrm{ha}^{-1}$ of pure life seeds, respectively. The plots sowed with only $B$. ruziziensis and $B$. brizantha $\mathrm{cv}$. Marandu were established with 4.0 and $5.0 \mathrm{~kg} \mathrm{ha}^{-1}$ of pure life seeds, respectively.

The $P$. glaucum L. sowing was accomplished in the space between rows of $50 \mathrm{~cm}$. The $P$. glaucum L. cultivar sowed was BRS 1501, which was used $11 \mathrm{~kg} \mathrm{ha}^{-1}$ of seeds. The intercropping fall-winter corn with $C$. spectabilis was accomplished with $6 \mathrm{~kg} \mathrm{ha}^{-1}$ of seeds in the space between rows of $45 \mathrm{~cm}$. The sowing of $C$. spectabilis was done manually 15 days after the winter corn sowed.

In the soybean sowing it was used an automatized machine. In the occasion of sowing in October of each year, it was accomplished the fertilizer with $380 \mathrm{~kg} \mathrm{ha}^{-1}$ of the formulation $02-20-20\left(\mathrm{~N}-\mathrm{P}_{2} \mathrm{O}_{5}-\mathrm{K}_{2} \mathrm{O}\right)$ in sowing furrow, this fertilizer recommendation was based on soil chemical results and soybean needs according to Cantaruttti et al. (1999). The soybean cultivar sowed was BMX Potência Roundup Ready (99\% of purity and $95 \%$ of germination). It was sowed 15 seeds per meter. The soybean seeds were treated with fungicide [Carboxin + Thiran $\left.\left(48 \mathrm{~g} \mathrm{~L}^{-1}\right)\right]$, insecticide [Fipronil $\left(40 \mathrm{~g} \mathrm{~L}^{-1}\right)$ ], micronutrients [cobalt $\left(2.32 \mathrm{~g} \mathrm{~L}^{-1}\right)$ and molybdenum $\left(40.6 \mathrm{~g} \mathrm{~L}^{-1}\right)$ ], and these doses were in gram of active ingredient per $80 \mathrm{~kg}$ of seeds. Besides, the seeds were inoculated before the sowing with inoculate in turf, which contented the bacteria Bradyrhizobium elkani (Race Semia 5019) and Bradyrhizobium japonicum (Race Semia 5079) in the concentration of $5 \times 10^{9}$ viable cells per gram of inoculate. It was used $100 \mathrm{~mL}$ of inoculate in each $80 \mathrm{~kg}$ of soybean seed. The desiccation of cover crops was accomplished 20 days before the soybean sowing, through the use of glyphosate-salt-isopropylamine $\left(1,440 \mathrm{~g} \mathrm{ha}^{-1}\right.$ of acid equivalent) plus $1,209 \mathrm{~g} \mathrm{ha}^{-1}$ of active ingredient of 2.4-D, dimethylamine salt.

\section{Soil measurement}

Soil samples were collected after desiccation of cover crops in September 2013. The measurements were taken in three soil depths $(0-5,5-10$ and 10-20 cm). The samples were collected in trenches. These trenches were made perpendicular to the sowing row. After collecting the composite soil sample, it was stored in a plastic bag, identified and forward to Soil Lab of Universidade Federal da Grande Dourados (UFGD) in Brazil to be analyzed. The following parameters were evaluated in the soil sample; $\mathrm{pH}_{\mathrm{CaCl} 2}\left(1: 2.5\right.$ ratio), total acidity $\mathrm{pH} 7.0\left(\mathrm{H}^{+}+\mathrm{Al}^{3+}\right)$, phosphorus content, exchangeable potassium, exchangeable aluminum, exchangeable calcium, exchangeable magnesium, base saturation, Cation Exchange Capacity (CEC) in $\mathrm{pH}=7.0$, base saturation $(\mathrm{BS} \%)$, calcium $(\% \mathrm{Ca})$, magnesium $(\% \mathrm{Mg})$, potassium saturation $(\% \mathrm{~K})$, following the methodology of Claessen (1997).

\section{Statistical analysis}

The variables assessed in this experiment were submitted to the analysis of variance (ANOVA) by the $F$-test, which was through a joint analysis between the cover crops and soil depths evaluated. The means were compared through the Tukey test of means $(p \leq 0.05)$. These tests were carried out with the use of SISVAR software (Ferrreira, 2010).

\section{Conclusion}

The cover crops evaluated in this research affected the exchangeable magnesium and potassium, as well as the magnesium and potassium saturation. The phosphorus content changed in response to cover crops, which was quite important to observe that this nutrient may increase the content with adoption of cover crops in no-till system. These species used in this research may be recommended to integrate a crop rotation system with the possibility of increasing phosphorus availability in soil. In Oxisol, as the case of this research site, the phosphorus content is the most limited nutrient in soil, the use of cover crops that improve its availability is a great step to become the no-till system sustainable.

\section{Acknowledgement}

The authors are grateful to Universidade Federal da Grande Dourados (UFGD) for the collaboration of researchers and Brazilian Federal Agency (Coordenação de Aperfeiçoamento de Pessoal de Nível Superior- CAPES) for the financial support to the accomplishment of this work.

\section{References}

Abdollahi L, Munkholm LJ (2013) Tillage system and cover crop effects on soil quality: I chemical, mechanical and biological properties. Soil Sci Soc Am J. 78(1):262-270.

Agbede TM (2010) Tillage and fertilizer effects on some soil properties, leaf nutrient concentrations, growth and sweet potato yield on an. Soil Till Res. 110(1):25-32.

Andriole I, Prado R de M (2012) Plantas de cobertura em pré-safra e adubação nitrogenada na fertilidade do solo em diferentes camadas, cultivado com milho em sistema de plantio direto e convencional. Semina Cienc Agr. 33(3):963-978.

Bassegio D, Santos RF, Secco D, Zanão JLA, Werncke I, Sarto MVM (2015) Short-term effects of crop rotations on soil chemical properties under no-tillage condition. Aust J Crop Sci. 9(1):49-54.

Calegari A, Tiecher T, Hargrove WL, Ralisch R, Tessier D, Tourdonnet S, Guimarães MF, Santos DR (2013) Longterm effect of different soil management systems and winter crops on soil acidity and vertical distribution of nutrients in a Brazilian Oxisol. Soil Till Res. 133:32-39.

Cantarutti RB, Barros NF, Martinez HEP, Novais RF (2006) Avaliação da fertilidade do solo e recomendação de fertilizantes. In: Novais RF, Venegas VHA, Barros NF, Fontes RLF, Cantarutti RB, Neves JCL, eds. Fertilidade do solo. Viçosa, SBCS, p.769-850.

Claessen, MEC (Org.) (1997) Manual de métodos de análises de solo. 2.ed. revisão atualizada. Rio de Janeiro: Embrapa Solos, 212p.

Cunha E de Q, Stone LF, Didonet AD, Ferreira EP de B, Moreira JAA, Leandro WM (2011) Atributos químicos de solo sob produção orgânica influenciados pelo preparo e por plantas de cobertura. Rev Bras Eng Agric Ambient. 15(10):1021-1029.

D'Haene K, Sleutel S, De Neve S, Gabriels D, Hofman G (2009) The effect of reduced tillage agriculture on carbono dynamics in silt loam soils. Nutr Cycling Agroecosyst. 84:249-265.

Dang YP, Moody PW, Bell MJ, Seymour NP, Dalal RC, Freebaim DM, Walker SR (2015) Strategic tillage in no-till farming systems in Australia's northern grains-growing 
regions: II. Implications for agronomy and environment. Soil Till Res.152:115-123.

Duda GP, Guerra JGM, Monteiro MT, De-polli H, Teixeira MG (2003) Perennial herbaceous legumes as live soil mulches and their effects on $\mathrm{C}, \mathrm{N}$ and $\mathrm{P}$ of the microbial biomass. Sci Agric. 60:139-147.

Eimil-Fraga C, Álvarez-Rodríguez E, Rodríguez-Soalleiro R, Fernández-Sanjurjo M (2015) Influence of parent material on the aluminium fractions in acidic soils under Pinus pinaster in Galicia (NW Spain). Geoderma. 255:50-57.

Ferreira DF (2010) Sisvar: versão 5.3. DEX/UFLA, Lavras.

Foloni JSS, Tiritan JC, Calonego JAJ (2008) Aplicação de fosfato natural e reciclagem de fósforo por milheto, braquiária, milho e soja. Rev Bras Cienc Solo. 32:11471155.

Garcia RA, Crusciol JC, Calonego CA, Rosolem CA (2008) Potassium cycling in a maize-brachiaria cropping system. Eur J Agron. 28:579-585.

Köppen W (1948) Climatologia: con un estudio de los climas de la tierra. México: Fondo de Cultura Económica, 478p.

Landry GM, Scow K, Brennan E (2014) Soil phosphorus mobilization in the rhizosphere of cover crops has little effect on phosphorus cycling in California agricultural soils. Soil Biol Biochem. 78:255-262.

Molina LR, Gonçalves LC, Rodriguez NM, Rodrigue JAS, Ferreira JJ, Ferreira VCP (2000) Agronomic evaluation of six sorghum hybrids (Sorghum bicolor (L.) Moench). Arq Bras Med Vet Zootec. 52:385-390.

Moreti D, Alves MC, Filho WVV, Carvalho M de P (2007) Atributos químicos de um latossolo vermelho sob diferentes sistemas de preparo, adubações e plantas de cobertura. Rev Bras Cienc Solo. 31(1):167-175.

Rheinheimer DS, Anghinoni I (2003) Accumulation of soil organic phosphorus by soil tillage and cropping systems in subtropical soils. Commun Soil Sci Plant Anal. 34:23392354.

Ribeiro AC, Guimaraes PTG, Alvarez VVH (Ed.) (1999) Recomendações para o uso de corretivos e fertilizantes em Minas Gerais: $5^{\mathrm{a}}$ aproximação. Viçosa: Comissão de Fertilidade do Solo do Estado de Minas Gerais, 1999. 359p.

Rosolem CA, Calonego JC (2013) Phosphorus and potassium budget in the soil-plant system in crop rotations under notill. Soil Till Res. 126:127-133.

Sá JC de M, Tiyel F, Lal R, Briedis C, Hartman DC, Santos JZ, Santos JB (2014) Long-term tillage systems impacts on soil $\mathrm{C}$ dynamics soil resilience and agronomic productivity of a Brazilian Oxisol. Soil Till Res. 136:38-50.

Santos HG, Jacomine PKT, Anjos LHC, Oliveira VA, Lubreras JF, Coelho MR, Almeida JA, Cunha TJF, Oliveira JB. (ed.) 2013. Sistema Brasileiro de Classificação de Solos. 3. edição revisada e ampliada. Brasília: Embrapa $353 \mathrm{p}$.
Steiner F, Pivetta LA, Castoldi G, Costa MSSM, Costa LA de M (2012) Phosphorus and potassium balance in soil under crop rotation and fertilization. Semina Cienc Agr. 33(6): 2173-2186.

Tiecher T, Rheinheimer DS, Calegari A (2012) Soil organic forms different soil management systems and winter crops in a long term experiment. Soil Till Res. 124:57-67.

Tilman D, Reich PB, Knops J, Wedin D, Mielke T, Lehman C (2001) Diversity and productivity in a long-term grassland experiment. Science. 294:843-845.

Torres JLR, Pereira MG, Fabian AJ (2008) Produção de fitomassa por plantas de cobertura e mineralização de seus resíduos em plantio direto. Pesqui Agropecu Bras. 43(3):421-428.

Wang Y, Hu C, Dong W, Li X, Zhang Y, Qin S, Oenema O (2015) Carbon budget of a winter-wheat and summermaize rotation cropland in the North China Plain. Agric Ecosyst Environ. 206:33-45.

Willekens K, Vandecasteele B, Buchan D, Neve S (2014) Soil quality is positively affected by reduced tillage and compost in an intensive vegetable cropping system. Appl Soil Ecol. 82: 61-71.

Zambrosi FCB, Alleoni LRF, Caires EF (2008) Liming and ionic speciation of an Oxisol under no-till system. Sci Agric. 65(2):190-203. 